\title{
BIRDS ASSOCIATED WITH AMERICAN ELM FORESTS IN NORTHEASTERN SASKATCHEWAN
}

Karen L. Wiebe1, Stan Shadick ${ }^{2}$

${ }^{1}$ Department of Biology, University of Saskatchewan, 112 Science Place, Saskatoon, SK, S7N 5E2; Email: <karen.wiebe@usask.ca>

${ }^{2}$ Department of Physics and Engineering Physics, University of Saskatchewan, 116 Science Place, Saskatoon, SK, S7N 5E2: Email: <stan.shadick@usask.ca>

\section{Introduction}

The American elm (Ulmus americana) forms a distinct forest ecosystem along rivers and valleys at the northeastern limit of its range on the Canadian prairies. Never widespread on the prairie landscape, these native elm forests are disappearing rapidly as a result of Dutch elm disease. The disease, caused by the fungus Ophiostoma ulmi and transmitted by a native bark beetle, was introduced to North America in the 1930s, and first appeared in Saskatchewan in the 1980s. ${ }^{1}$ Despite efforts to control it, the disease front continues to move westwards and threatens both natural and urban elm forests in Saskatchewan and Alberta.

Nature Saskatchewan administers a nature reserve in elm forest obtained from Alex Rendek in 1989*. The Rendek Elm Forest Sanctuary is located about $14 \mathrm{~km}$ northeast of the city of Hudson Bay on the banks of the Red Deer River. Tragically, the area was hit by Dutch elm disease beginning around 2001, and today most of the mature wild elms in the region are dead. Harms and Baker $(1998)^{2}$ conducted a bioinventory of vascular plants on the site, but there has been no systematic inventory of birds in the elm forests of northeastern Saskatchewan. With the knowledge that the disease front was advancing towards Saskatchewan, in 1998 we established 30 point-count stations in riparian forests dominated by American elm along the Red Deer River, near the border of Saskatchewan and Manitoba. Our goal was to quantify the densities of bird species in elm forests prior to disease, in order to obtain a benchmark that could be compared to potential changes to bird communities in subsequent decades after the infection.

\section{Methods}

We placed 10 of the 30 stations within the 15-ha Rendek Elm Forest Nature Reserve operated by Nature Saskatchewan $\left(52^{\circ}\right.$ $\left.54^{\prime} \mathrm{N}, 102^{\circ} 01^{\prime} \mathrm{W}\right)$. Eight stations were located on a river oxbow peninsula about $2.5 \mathrm{~km}$ to the east of Rendek on a plot named "Tongue" encompassing about 18 ha, and the remaining 12 stations were on another 18-ha oxbow peninsula about 20 km farther east downstream called "Fort". On each of the three sites, stations were a minimum of $100 \mathrm{~m}$ apart and spaced on linear transects. At this latitude, elms grow mainly along bottomlands and floodplains, while upslope forests are mixed-wood boreal and dominated by white spruce (Picea glauca), black spruce ( $P$. mariana), jack pine (Pinus contorta), and trembling aspen (Populus tremuloides). Briefly, the canopy is dominated by the elm, with Manitoba maple (Acer negundo) the second most common tree. The shrub layer is dominated by choke-cherry (Prunus virginiana), red-osier dogwood (Cornus stolonifera), high-bush cranberry (Viburnum trilobum), and red elderberry 
(Sambucus racemosa). The dominant plant of the forb layer is the ostrich fern (Matteuccia struthiopteris). ${ }^{2}$

One observer (K.L.W.) quantified vegetation structure surrounding the point count stations. The species and diameter at breast height (DBH, ca. $1.4 \mathrm{~m}$ above ground level) of each tree or standing snag was recorded within a 12-m radius of the station. A tree was defined as having a $\mathrm{DBH}>12 \mathrm{~cm}$, and it was classified into decay classes ranging from 1 (completely healthy) to 5 (decayed, broken stub). ${ }^{3}$ The number of deadfalls (logs) that were $>12 \mathrm{~cm}$ diameter was also recorded. At the shrub layer (between 2 and $5 \mathrm{~m}$ tall), the percent coverage of the main species in the 12-m radius plot was estimated visually, i.e., percent pin cherry, elder, maple, and elm saplings. At the forb layer, the percent coverage of all forb species combined was recorded, as well as the coverage by the dominant species, the ostrich fern.

Corresponding bird surveys were conducted during three years (1999-2001) prior to disease. Point counts were done in a $50-\mathrm{m}$ fixed-radius plot following standard recommended protocols for such surveys. ${ }^{4,5}$ Each station was surveyed three times during the season to encompass the peak singing times of different bird species in the community: end of May, end of June, and third week of July. The same observer (S.S.) conducted the first two rounds of bird counts while K.L.W. did the late July surveys. All birds were censused between 06:00 and 10:00 $\mathrm{h}$ on days it was not raining. All species seen or heard during a 5- to 7-min count period were recorded, and their positions and movements were noted on a sheet of paper to avoid doublecounting individuals. After an initial $5 \mathrm{~min}$, tape-recorded calls of four woodpeckers were played in sequence (hairy, downy, and pileated woodpeckers and yellowbellied sapsucker) at alternate stations, and the observer waited an additional 2 min to record any new individuals.

Only observations within the $50-\mathrm{m}$ radius ( $0.785 \mathrm{ha}$ ) were used to calculate bird densities on the plots, ignoring individuals soaring or flying above the plot. ${ }^{6}$ For a given breeding season, we used the highest count of individuals of each species in the plot as an index of abundance of the species at that point. 7,8 The three annual estimates of bird density collected during the three sampling years were then averaged for an estimate of bird abundances for each point count station. We also kept a list of birds seen near the perimeter of the plots, or flying overhead, and report them without abundances.

\section{Results and Discussion}

The three study plots did not differ in densities of mature American elm trees, which averaged about 150 trees/ha (Table 1). However, there were more Manitoba maple, trembling aspen, and cottonwood (Populus balsamifera) trees in the canopies of the Rendek and Tongue sites compared to the Fort site, so the total density of trees on the former two sites was higher than at the Fort. The average size (and hence probable age) of the elms was greatest on the Fort site, whereas the Tongue site had the greatest number of standing snags compared to the other areas. There was no difference in the amount of deadfall on the ground among the three study plots.

The understory (shrub layer) was significantly denser at the Rendek site compared to the others, and because the shrubs may have shaded the plants below them on the forest floor, there was a negative relationship between the amount of shrub cover and the forb cover on the plots. The Fort site had the sparsest shrub layer, but $91 \%$ of the ground was covered by forbs, mainly the dominant ostrich fern. In general, the Fort site was characterized by the largest elms, a canopy most 
Table 1. Vegetation structure and composition within three forest sites dominated by American elm Ulmus americana. The three study sites are located along the Red Deer River in northeastern Saskatchewan. Vegetation was measured in 1999 , prior to infection of the elms by Dutch elm disease. Means and standard deviations of the variables are shown, with sample sizes indicating the number of 0.785 -ha plots at each site. Statistics are the $F$ - and p-values of an analysis of variance testing for differences across the three sites. Significant differences are assumed for $p \leq 0.05$. DBH: diameter at breast height (ca. $1.4 \mathrm{~m}$ above ground level).

\begin{tabular}{|lllll|}
\hline Variable & \multicolumn{3}{c|}{ Site } & $F(p)$ \\
\cline { 2 - 5 } & Rendek $(n=10)$ & Tongue $(n=8)$ & Fort $(n=12)$ \\
\hline $\begin{array}{l}\text { Live elm density } \\
\text { (no./ha) }\end{array}$ & $133 \pm 106$ & $166 \pm 122$ & $166 \pm 130$ & $0.25(0.78)$ \\
$\begin{array}{l}\text { Total tree density } \\
\text { (no./ha) }\end{array}$ & $280 \pm 58$ & $342 \pm 145$ & $268 \pm 88$ & $4.02(0.03)$ \\
$\begin{array}{l}\text { Mean elm DBH } \\
\text { (cm) }\end{array}$ & $41 \pm 16$ & $33.4 \pm 9.3$ & $50 \pm 17$ & $3.2(0.05)$ \\
$\begin{array}{l}\text { Snag density } \\
\text { (no./ha) }\end{array}$ & $16 \pm 21$ & $33 \pm 21$ & $11+18$ & $3.2(0.05)$ \\
$\begin{array}{l}\text { Deadfall density } \\
\text { (no./ha) } \\
\% \text { shrub cover }\end{array}$ & $46 \pm 35$ & $47 \pm 40$ & $55 \pm 50$ & $0.14(0.86)$ \\
$\begin{array}{l}\text { \% total forb } \\
\text { cover } \\
\% \text { fern cover }\end{array}$ & $50 \pm 33$ & $26 \pm 19$ & $22 \pm 11$ & $14.0(0.001)$ \\
\hline
\end{tabular}

dominated by the elms, and few shrubs but a luxuriant mat of ferns. Rendek had the densest shrub layer, whereas Tongue had a shrub and forb layer intermediate in density between the other two sites.

A total of 72 bird species was seen on or from the three sites (Table 2). Of these, 49 species were tabulated within the pointcount circles and could be considered associated with, and probably breeding in, the elm forest. In general, the red-eyed vireo (see Table 2 for scientific names) was the most common bird, ranking first or second in abundance at all three sites (Table 3). Other species that were abundant across all sites were the American redstart, white-throated sparrow, rose-breasted grosbeak, mourning warbler, and ovenbird. Whereas least flycatchers were common at the Rendek and Tongue sites, they were much rarer at the Fort. However, the latter site had the greatest diversity of warblers, including abundant black-throated green and blackburnian (Table 3 ), and it was the only site with winter wrens, which also occurred in high densities. Black-throated green warblers prefer "middle-aged and mature" forests, ${ }^{9}$ and winter wrens also prefer mature forests with large trees and many snags and fallen logs, ${ }^{10}$ so the Fort site may have been especially attractive 
because of the larger and older trees there. Alternatively, the greater diversity of species at the Fort may have occurred because it was surrounded by more unbroken forest compared to the other sites which were bounded on one side by farmland.

To our knowledge, all the species recorded on our surveys were within previously documented ranges. However, our data are the first to provide estimates of breeding densities of birds in a healthy, native elm forest on the northern prairies. It is our hope that these data will be a valuable historical benchmark as the structure and composition of the elm forest is likely to undergo dramatic changes in the coming years as a consequence of Dutch elm disease.

Table 2. Densities (no. individuals/ha) of birds observed within point count plots in three elm forest sites in Saskatchewan. For each point count station, an average density was calculated based on three years of observations (1999-2001), and then point count stations were averaged within each site. Birds observed from the site (e.g. flying overhead), or at the perimeter of the sites, but not within the count plots are shown without calculated densities. Species are arranged in taxonomic order.

\begin{tabular}{|c|c|c|c|c|}
\hline \multirow[t]{2}{*}{ Common name } & \multirow[t]{2}{*}{ Latin name } & \multicolumn{3}{|c|}{ Site name } \\
\hline & & Rendek & Tongue & Fort \\
\hline American white pelican & $\begin{array}{l}\text { Pelecanus } \\
\text { erythrorhynchos }\end{array}$ & & & July \\
\hline $\begin{array}{l}\text { Double-crested } \\
\text { cormorant }\end{array}$ & Phalacrocorax auritus & & & June \\
\hline Great blue heron & Ardea herodius & & & June \\
\hline Canada goose & Branta canadensis & & June & June \\
\hline Wood duck & Aix sponsa & June & & \\
\hline Mallard & Anas platyrhynchos & June & July & June \\
\hline Common goldeneye & Bucephala clangula & June & June & June/July \\
\hline Common merganser & Mergus merganser & & & June \\
\hline American kestrel & Falco sparverius & May & & \\
\hline Broad-winged hawk & Buteo platypterus & 0 & 0.053 & 0 \\
\hline Red-tailed hawk & Buteo jamaicensis & July & May, June & \\
\hline Ruffed grouse & Bonasa umbellus & 0.29 & 0.22 & 0 \\
\hline Sandhill crane & Grus canadensis & & & June \\
\hline Killdeer & Charadrius vociferus & & & June \\
\hline Spotted sandpiper & Actitis macularia & & May & \\
\hline Common tern & Sterna hirundo & & June & \\
\hline Barred owl & Strix varia & June & & \\
\hline Common nighthawk & Chordeiles minor & June & & July \\
\hline $\begin{array}{l}\text { Ruby-throated } \\
\text { hummingbird }\end{array}$ & Archilochus colubris & 0.063 & 0 & 0 \\
\hline
\end{tabular}


Table 2, continued

\begin{tabular}{|c|c|c|c|c|}
\hline Belted kingfisher & Ceryle alcyon & May/June & June & \\
\hline $\begin{array}{l}\text { Yellow-bellied } \\
\text { sapsucker }\end{array}$ & Sphyrapicus varius & 0.13 & 0.05 & 0.17 \\
\hline Downy woodpecker & Picoides pubescens & 0.22 & 0.22 & 0.32 \\
\hline Hairy woodpecker & Picoides villosus & 0.29 & 0 & 0.27 \\
\hline Northern flicker & Colaptes cafer & 0.04 & 0.11 & 0.22 \\
\hline Pileated woodpecker & Dryocopus pileatus & 0.17 & 0.10 & 0.10 \\
\hline Olive-sided flycatcher & Contopus cooperi & June & & \\
\hline Alder flycatcher & Empidonax alnorum & 0.09 & 0.05 & 0.05 \\
\hline Least flycatcher & Empidonax minimus & 1.31 & 1.64 & 0.17 \\
\hline Eastern phoebe & Sayornis phoebe & 0.04 & 0 & 0.05 \\
\hline Great crested flycatcher & Myiarchus crinitus & 0 & 0.05 & 0.10 \\
\hline Bank swallow & Riparia riparia & June & June & June \\
\hline Barn swallow & Hirundo rustica & July & & \\
\hline Gray jay & Perisoreus canadensis & & June & \\
\hline Blue jay & Cyanocitta cristata & 0.06 & 0.08 & 0.05 \\
\hline American crow & Corvus brachyrhynchos & 0.13 & 0.10 & 0.06 \\
\hline Common raven & Corvus corax & 0.12 & 0.11 & 0.20 \\
\hline Black-billed magpie & Pica hudsonia & 0.06 & 0 & 0 \\
\hline $\begin{array}{l}\text { Black-capped } \\
\text { chickadee }\end{array}$ & Poecile atricapilla & 0.09 & 0.22 & 0.05 \\
\hline Red-breasted nuthatch & Sitta canadensis & 0.09 & 0 & 0.05 \\
\hline $\begin{array}{l}\text { White-breasted } \\
\text { nuthatch }\end{array}$ & Sitta carolinensis & 0.55 & 0.32 & 0.37 \\
\hline Winter wren & Troglodytes troglodytes & 0 & 0 & 1.01 \\
\hline Veery & Catharus fuscescens & 0.73 & 1.22 & 0.05 \\
\hline Swainson's thrush & Catharus ustulatus & 0.93 & 0.22 & 0.59 \\
\hline American robin & Turdus migratorius & 0.64 & 0.54 & 0 \\
\hline Cedar waxwing & Bombycilla cedrorum & 0.22 & 0.22 & 0.10 \\
\hline Philadelphia vireo & Vireo philadelphicus & 0.09 & 0.22 & 0.22 \\
\hline Red-eyed vireo & Vireo olivaceus & 1.82 & 1.86 & 1.54 \\
\hline Tennessee warbler & Vermivora peregrina & 0 & 0.11 & 0 \\
\hline Yellow warbler & Dendroica petechia & 0.80 & 0.64 & 0 \\
\hline Chestnut-sided warbler & Dendroica pensylvanica & 0.04 & 0.22 & 0.74 \\
\hline Yellow-rumped warbler & Dendroica coronata & 0 & 0.05 & 0 \\
\hline $\begin{array}{l}\text { Black-throated } \\
\text { green warbler }\end{array}$ & Dendroica virens & 0 & 0 & 1.44 \\
\hline
\end{tabular}


Table 2, continued

\begin{tabular}{|lllll|}
\hline Blackburnian warbler & Dendroica fusca & 0 & 0 & 1.06 \\
Black-and-white & Mniotilta varia & 0.09 & 0 & 0.48 \\
warbler & & & & \\
American redstart & Setophaga ruticilla & 2.42 & 1.81 & 0.69 \\
Ovenbird & Seiurus aurocapillus & 0.89 & 0.85 & 0.85 \\
Northern waterthrush & Seiurus noveboracensis & 0.55 & 0.59 & 0.1 \\
Mourning warbler & Oporornis philadelphia & 0.68 & 0.69 & 1.27 \\
Connecticut warbler & Oporornis agilis & 0 & 0 & 0.035 \\
Common yellowthroat & Geothlypis trichas & 0 & 0.26 & 0.05 \\
Wilson's warbler & Wilsonia pusilla & 0 & 0 & 0.05 \\
Canada warbler & Wilsonia canadensis & 0 & 0.17 & 0.22 \\
Rose-breasted & Pheucticus ludovicianus & 0.85 & 1.64 & 0.59 \\
grosbeak & & & & \\
Clay-colored sparrow & Spizella palida & May & & \\
Chipping sparrow & Spizella passerina & 0.09 & 0.10 & 0 \\
Song sparrow & Melospiza melodia & 0.38 & 0.48 & 0.37 \\
White-throated sparrow & Zonotrichia albicollis & 1.61 & 0.69 & 1.54 \\
White-crowned sparrow & Zonotrichia leucophrys & & May & \\
Brown-headed cowbird & Molothrus ater & 0.13 & 0.17 & 0 \\
\hline
\end{tabular}

Table 3. Relative abundances of bird species on three study plots in elm forest of northeastern Saskatchewan. The ten most abundant species on each plot are listed with their density (no./ha) in parentheses, starting with the most abundant. See Table 2 for scientific names.

\begin{tabular}{|c|c|c|c|}
\hline \multirow[t]{2}{*}{ Rank } & \multicolumn{3}{|c|}{ Site } \\
\hline & Rendek & Tongue & Fort \\
\hline 1 & American redstart (2.42) & Red-eyed vireo (1.86) & Red-eyed vireo (1.54) \\
\hline 2 & Red-eyed vireo (1.82) & American redstart (1.81) & White-throated sparrow (1.54) \\
\hline 3 & $\begin{array}{l}\text { White-throated sparrow } \\
\qquad(1.61)\end{array}$ & Least flycatcher (1.64) & $\begin{array}{l}\text { Black-throated green warbler } \\
\qquad(1.44)\end{array}$ \\
\hline 4 & Least flycatcher (1.31) & Rose-breasted grosbeak (1.64) & Mourning warbler (1.27) \\
\hline 5 & Swainson's thrush $(0.93)$ & Veery (1.22) & Blackburnian warbler (1.06) \\
\hline 6 & Ovenbird (0.89) & Ovenbird (0.85) & Winter wren (1.01) \\
\hline 7 & $\begin{array}{l}\text { Rose-breasted grosbeak } \\
(0.85)\end{array}$ & Mourning warbler (0.69) & Ovenbird $(0.85)$ \\
\hline 8 & Yellow warbler $(0.80)$ & White-throated sparrow (0.69) & American redstart (0.69) \\
\hline 9 & Veery $(0.73)$ & American goldfinch (0.69) & Swainson's thrush (0.59) \\
\hline 10 & Mourning warbler (0.68) & Yellow warbler (0.64) & Rose-breasted grosbeak (0.59) \\
\hline
\end{tabular}




\section{Acknowledgements}

We are grateful to the various people who assisted with the bird surveys in challenging conditions: Michael Williams (1999), Maureen Scharf and Frank Roy (2000), and Tony Allen and Candace Neufeld (2001). Funding for the project came from an NSERC discovery grant to K.L.W.

1. Hubbes M (1999) The American elm and Dutch elm disease. Forestry Chronicle 75:265-273.

2. Harms V, Baker L (1998) A preliminary floral list for the Rendek Elm Forest Nature Sanctuary in eastcentral Saskatchewan. Blue Jay 56:213-215.

3. Wiebe KL (2001) Microclimate of tree cavity nests: is it important for reproductive success in northern flickers? Auk 118:412-421.

4. Hutto RL, Pletschet SM, Hendricks P (1986) A fixed-radius point-count method for nonbreeding and breeding season use. Auk 103:593-602.

5. Martin TE, Paine CR, Conway CJ, Hochachka WM, Allen P, Jenkins W (1997) BBIRD field protocol. Montana Cooperative Wildlife Research Unit, US Geological Survey. University of Montana, Missoula, MT.
6. Robinson WD, Robinson SK (1999) Effects of selective logging on forest bird populations in a fragmented landscape. Conservation Biology 31:58-66.

7. Hagan JM, McKinley PS, Meehan AL, Grove SL (1997) Diversity and abundance of landbirds in a north-eastern industrial forest. Journal of Wildlife Management 61:718-735.

8. Tingley MW, Orwig DA, Field R, Motzkin G (2002). Avian response to removal of a forest dominant: consequences of hemlock woolly adelgid infestations. Journal of Biogeography 29:1505-1516.

9. Morse DH (1976) Variables determining the density and territory size of breeding spruce-woods warblers. Ecology 57:290-301.

10. Hansen AJ, McComb WC, Vega R, Raphael MG, Hunter M (1995) Bird habitat relationships in natural and managed forests in the west Cascades. Ecological Applications 5:555-569.

'EDITORS' NOTE: For more on Alexander Rendek and the Rendek Elm Forest, see: Peschken D (2009) In memoriam: Alexander Rendek (1932-2009). Blue Jay 67:123-124.

You must teach your children that the ground beneath their feet is the ashes of your grandfathers. So that they will respect the land, tell your children that the earth is rich with the lives of our kin. Teach your children what we have taught our children, that the earth is our mother. Whatever befalls the earth befalls the sons of the earth. If men spit upon the ground, they spit upon themselves. 